\title{
Increase in pro-apoptotic Bax expression and decrease in anti-apoptotic Bcl-2 expression in newborns with necrotizing enterocolitis
}

\author{
Ufuk Ates M.D. ${ }^{a}$, Gulnur Gollu M.D. ${ }^{a}$, Gonul Kucuk M.D. ${ }^{a}$, Deniz Billur M.D. ${ }^{b}$, Meltem Bingol-Kologlu M.D. ${ }^{a}$, \\ Yavuz Yllmaz.M.D. ${ }^{c}$, Hulya Ozkan-Ulu M.D. ${ }^{c}$, Pinar Bayram M.D. ${ }^{b}$, Emin BagriacikM.D. ${ }^{d}$ and Huseyin Dindar M.D. ${ }^{a}$
}

\begin{abstract}
Background/Aim. The aim of the present study was to find out if there is an increase in the expression of pro-apoptotic Bax and reduction in expression of anti-apoptotic Blc-2A1 in newborn intestines with necrotizing enterocolitis (NEC).

Material and Methods. We compared 8 consecutive newborn patients undergoing bowel resection for NEC with 8 neonates undergoing intestinal resection for ileal atresia.

Histopathological evaluation of tissue injury and apoptosis was performed by using light microscopic examination and TUNEL method. The mRNA level of apoptotic (CASP3, CASP6, CASP7, Bax, BIRC2) and anti-apoptotic genes were evaluated by PCR array method. Protein expression was assessed by immunohistochemistry.

Results. Tissue injury scores and mean apoptosis scores were significantly higher in NEC group when compared with control group $(p<0.01)$. Expression of pro-apoptotic genes were significantly increased in NEC group when compared with control group $(\mathrm{p}<0.01)$. Expression of anti-apoptotic Bcl2A1 gene was significantly decreased in NEC group, $(\mathrm{p}<0.01)$. Protein expression of Bax and CASP 3 was significantly increased in NEC group, $(\mathrm{p}<0.01)$.

Conclusion. Ourdata in humannewborns suggest that alteration of the balance between pro-apoptotic Bax expression and antiapoptotic Bcl-2A1 expression in the site of injury is a possible mechanism in the pathogenesis of NEC.
\end{abstract}

Keywords: apoptosis, gene expression, necrotizing enterocolitis, newborn.

http:/ /dx.doi.org/10.5546/aap.2016.eng.243

a. Ankara University, School of Medicine, Department of Pediatric Surgery, Ankara, Turkey.

b. Ankara University School of Medicine, Department of Histology and Embryology, Ankara, Turkey.

c. Zekai Tahir Burak Woman Health Education and Research Hospital, Department of Pediatric Surgery, Ankara, Turkey.

d. Gazi University, School of Medicine, Immunology Research Center, Ankara, Turkey.

E-mail address: Ufuk Ates M.D.: drufukates@gmail.com

Funding: None.

Conflict of interest: None.

Received: 12-10-2015

Accepted: 2-24-2016

\section{INTRODUCTION}

Necrotizing enterocolitis (NEC) is a complicated, multi-factorial condition of newborns and premature infants which causes significant mortality and morbidity in this population. NEC is characterized by intestinal epithelial cell apoptosis, necrosis, haemorrhage, incomplete enterocyte migration, and proliferation that results in persistent gut barrier failure which leads to loss of epithelial integrity, invasion of the intestine by bacteria followed by an acute, hyper-reactive inflammatory reaction and consecutive bowel necrosis. ${ }^{1,2}$

The balance between cell proliferation and cell loss is necessary for the maintenance of intestinal epithelial homeostasis. ${ }^{3,4}$ The majority of cell loss in the normal intestine occurs by apoptosis. ${ }^{3}$ The balance of pro-apoptotic and anti-apoptotic proteins is crucial for cell survival. ${ }^{3} \mathrm{Bcl}-2$ family is a significant class of molecules that control enterocyte apoptosis. ${ }^{3} \mathrm{Bcl}-2 \mathrm{~A} 1$ is an antiapoptotic protein which inhibits the cytochrome $c$ release from the mitochondria and reverses the effects of the pro-apoptotic protein Bax. ${ }^{3}$ It has been showed that an exaggerated epithelial apoptosis in gut leads to severe NEC injury. . $3,5^{3,5}$ In a rat model of NEC, it has been shown that expression of apoptotic genes increased whereas expression of anti-apoptotic genes decreased. Furthermore, prevention and reducing apoptosis in experimental settings have been suggested to reduce NEC incidence..$^{5-7}$ Therefore, we aimed to find out if there is an increase in the expression of pro-apoptotic genes and reduction in expression of anti-apoptotic genes in newborn intestine with severe NEC and compared with intestines of newborns with ileal atresia. We especially focused on expression of pro-apoptotic Bax and caspase-3 and anti-apoptotic Bcl -2A1 genes.

\section{MATERIAL AND METHODS}

The Ethics Committee at Ankara University, School of Medicine, approved the collection of operative specimens for experimental purposes (Protocol No: 13-271). The study was carried 
out in accordance with the Helsinki Declaration. Informed consents were obtained from the parents. We compared 8 newborn patients undergoing bowel resection for NEC with 8 neonates undergoing intestinal resection for ileal atresia. Presence of free air and portal venous gas in direct radiograms, clinical deterioration while receiving optimal medical management were the criteria for surgical exploration in newborns with NEC. Diagnosis of NEC was confirmed during routine pathologic investigation. At laparotomy, $1 \times 1 \mathrm{~cm}$ ileal segments of the surgical specimens were obtained and divided into two pieces. One of them was snap-frozen in liquid nitrogen at $-80^{\circ} \mathrm{C}$ for polymerase chain reaction (PCR) studies and the other was reserved in formaldehyde for histopathological examination. Histopathological evaluation of tissue injury was performed by using light microscopic examination and tissue injury grading score. Histopathological evaluation of apoptosis was performed by terminal deoxynucleotidyl transferase mediated dUPT-FITC nick end labeling (TUNEL) method. ${ }^{2,8}$ The messenger ribonucleic acid (mRNA) levels of apoptotic and anti-apoptotic genes were evaluated by PCR Array method. ${ }^{9}$ Protein expression of these genes was assessed by immunohistochemistry. ${ }^{10}$

TABLE 1: Clinical characteristics, tissue injury and apoptosis scores of the patients in necrotizing enterocolitis (NEC) group

\begin{tabular}{|c|c|c|c|c|c|c|c|c|}
\hline $\begin{array}{l}\text { NEC } \\
\text { group } \\
\text { Patient }\end{array}$ & $\begin{array}{l}\text { Gender } \\
\text { its }\end{array}$ & $\begin{array}{c}\text { Gestational } \\
\text { Age } \\
\text { (weeks) } \\
\end{array}$ & $\begin{array}{c}\text { Age at } \\
\text { operation } \\
\text { (days) }\end{array}$ & $\begin{array}{l}\text { Weight } \\
\text { (gram) }\end{array}$ & $\begin{array}{c}\text { Extent of bowel } \\
\text { compromise } \\
\text { at operation } \\
\end{array}$ & $\begin{array}{l}\text { Operative } \\
\text { procedure }\end{array}$ & $\begin{array}{c}\text { Tissue } \\
\text { injury grading } \\
\text { system score } \\
\end{array}$ & $\begin{array}{l}\text { Apoptosis } \\
\text { score }\end{array}$ \\
\hline 1 & Male & 30 & 20 & 1250 & $\begin{array}{c}15 \mathrm{~cm} \\
\text { bowel necrosis }\end{array}$ & $\begin{array}{l}\text { Ileal resection } \\
\text { and ileostomy }\end{array}$ & 3 & 3 \\
\hline 2 & Female & 25 & 7 & 760 & $\begin{array}{c}25 \mathrm{~cm} \text { bowel } \\
\text { necrosis and perforation }\end{array}$ & $\begin{array}{l}\text { Ileocolic resection } \\
\text { and ileostomy }\end{array}$ & 4 & 4 \\
\hline 3 & Female & 32 & 15 & 1530 & $\begin{array}{l}30 \mathrm{~cm} \text { bowel } \\
\text { necrosis and perforation }\end{array}$ & $\begin{array}{l}\text { Ileocolic resection } \\
\text { and ileostomy }\end{array}$ & 4 & 4 \\
\hline 4 & Male & 27 & 17 & 850 & $\begin{array}{l}20 \mathrm{~cm} \text { bowel } \\
\text { necrosis and perforation }\end{array}$ & $\begin{array}{l}\text { Ileocolic resection } \\
\text { and ileostomy }\end{array}$ & 3 & 4 \\
\hline 5 & Male & 33 & 11 & 1600 & $\begin{array}{c}35 \mathrm{~cm} \text { bowel } \\
\text { necrosis and perforation }\end{array}$ & $\begin{array}{l}\text { Ileocolic resection } \\
\text { and ileostomy }\end{array}$ & 4 & 4 \\
\hline 6 & Male & 31 & 10 & 1420 & $\begin{array}{l}10 \mathrm{~cm} \text { bowel } \\
\text { necrosis }\end{array}$ & $\begin{array}{l}\text { Ileal resection } \\
\text { and ileostomy }\end{array}$ & 2 & 3 \\
\hline 7 & Female & 29 & 8 & 1050 & $\begin{array}{l}15 \mathrm{~cm} \text { bowel } \\
\text { necrosis and perforation }\end{array}$ & $\begin{array}{l}\text { Ileocolic resection } \\
\text { and ileostomy }\end{array}$ & 3 & 3 \\
\hline 8 & Male & 28 & 12 & 930 & $\begin{array}{c}15 \mathrm{~cm} \text { bowel } \\
\text { necrosis and perforation }\end{array}$ & $\begin{array}{l}\text { Ileal resection } \\
\text { and ileostomy }\end{array}$ & 2 & 3 \\
\hline
\end{tabular}

$\mathrm{cm}$ : centimeter

TABLE 2: Clinical characteristics, tissue injury and apoptosis scores of the patients in ileal atresia group

\begin{tabular}{lccccccc}
\hline $\begin{array}{l}\text { Ileal } \\
\text { Atresia } \\
\begin{array}{l}\text { Group } \\
\text { Patients }\end{array}\end{array}$ & Gender & $\begin{array}{c}\text { Gestational } \\
\text { Age } \\
\text { (weeks) }\end{array}$ & $\begin{array}{c}\text { Age at } \\
\text { operation } \\
\text { (days) }\end{array}$ & $\begin{array}{c}\text { Weight } \\
\text { (gram) }\end{array}$ & $\begin{array}{c}\text { Findings at operation } \\
\text { and operative procedure }\end{array}$ & $\begin{array}{c}\text { Tissue } \\
\text { injury grading } \\
\text { system score }\end{array}$ & $\begin{array}{c}\text { Apoptosis } \\
\text { score }\end{array}$ \\
\hline 1 & Female & 32 & 3 & 1600 & Type 3A ileal atresia ileoileal anastomosis & 2 & 2 \\
2 & Male & 36 & 2 & 2200 & Type 2 ileal atresia ileoileal anastomosis & 1 & 1 \\
3 & Male & 38 & 2 & 3100 & Type 2 ileal atresia ileoileal anastomosis & 1 & 1 \\
4 & Female & 33 & 4 & 1540 & multiple ileal atresia Two ileoileal anastomosis & 3 & 3 \\
5 & Female & 40 & 2 & 3300 & Type 2 ileal atresia ileoileal anastomosis & 1 & 1 \\
6 & Male & 38 & 2 & 2700 & Type 3A ileal atresia ileoileal anastomosis & 1 & 2 \\
7 & Female & 37 & 2 & 2750 & Type 1 ileal atresia ileoileal anastomosis & 1 & 1 \\
8 & Male & 38 & 2 & 2930 & Type 2 ileal atresia ileoileal anastomosis & 1 & 1 \\
\hline
\end{tabular}




\section{Statistical analysis}

Apoptotic score and tissue injury grades were statistically evaluated by using the Mann-Whitney $\mathrm{U}$ test. Gene transcription studies and protein expressions were evaluated by Student's t-test. Statistical significance was considered as $\mathrm{p}<0.01$.

\section{RESULTS}

The clinical characteristics of the control (ileal atresia) and NEC groups are presented in Tables 1 and 2. The control patients had a significantly higher weight than the NEC cases. All NEC patients were premature and their mean gestational age at birth was $29.3 \pm 2.6$ weeks and their mean weight at surgery time was $1171 \pm 321 \mathrm{~g}$. Median age of NEC group was 12.5 days (7-20) and median age of control group was 2.3 days..$^{2-4}$ Two of the eight control patients were premature infants. Control patients mean gestational age at birth was $36.5 \pm 2.7$ weeks and their mean weight at surgery time was $2515 \pm 666 \mathrm{~g}$. Indications for surgery in NEC group included pneumoperitoneum $(n=5)$ and failure of medical management associated with persistent dilated loop on x-ray $(n=2)$ or portal venous air $(n=1)$. All NEC cases had significant bowel necrosis which required bowel resection and ileostomy at surgery. In all control patients ileal atresia was corrected by ileoileal anastomosis.

Light microscopic evaluation of the samples stained with H\&E revealed minimal separation of superficialepithelial cells from lamina propria in 6 patients with ileal atresia. Submucosal separation in one patient and both submucosal and lamina propria separation in the remaining patient was encountered. The patient who had both submucosal and lamina propria separation was a premature infant with type IV atresia. Severe separation of submucosa and lamina propia, edema in submucosa and muscular layer and loss of epithelial integrity was present in 4 patients with NEC. Transmural necrosis was evident in the other 4 patients with NEC. Tissue injury grading scores according to groups are shown in Table 3. Tissue injury scores were significantly higher in NEC group when compared with control group $(3.3 \pm 0.8$ versus $1.5 \pm 0.8, p<0.01)$.

Mild apoptosis in the superficial epithelium and apoptosis including villi and crypts was encountered in samples from 7 and 1 patients with ileal atresia, respectively. All samples from the patients with NEC revealed either apoptosis including villi and crypts (n: 4) or transmural apoptosis(n: 4). The results of apoptosis scores according to groups are shown in Table 4. The mean apoptosis scores were significantly higher in the NEC group when compared with those in control group, $(3.5 \pm 0.5$ versus $1.6 \pm 0.5, p<0.01)$.

The difference in the expression of apoptotic and anti-apoptotic genes between groups are shown in Table 5 . The mRNA level of proapoptotic genes which are caspase-3, caspase-6, caspase-7, BIRC2 and Bax genes were significantly increased in NEC group when compared with control group $(p<0.01)$. mRNA levels of antiapoptotic Bcl-2A1 gene were significantly decreased in NEC group when compared with control group $(p<0.01)$. However, there was no statistically significant difference in mRNA levels of caspase-1, caspase-2, caspase- 9 Bad, Bcl- $\mathrm{X}_{\mathrm{L}}$ and Bcl-w genes between two groups.

Protein expression values are shown in Table 6. Mean protein expression percentage of Bax and Caspase 3 was significantly elevated in NEC group when compared withileal atresia group.

TABLE 3: Tissue injury grades according to groups

\begin{tabular}{lccccc}
\hline Groups & Grade 0 & Grade 1 & Grade 2 & Grade 3 & Grade 4 \\
\hline Necrotizing Enterocolitis Group $(\mathrm{n}=8)$ & - & - & 2 & 3 & 3 \\
Control Group $(\mathrm{n}=8)$ & - & 6 & 1 & 1 & - \\
\hline
\end{tabular}

TABLE 4: Apoptosis scores according to groups

\begin{tabular}{lcccc}
\hline Groups & Score 0 & Score 1 & Score 2 & Score 3 \\
\hline Necrotizing Enterocolitis Group $(\mathrm{n}=8)$ & - & - & Score 4 & 4 \\
Control Group $(\mathrm{n}=8)$ & - & 5 & 2 & 4 \\
\hline
\end{tabular}




\section{DISCUSSION}

This study showed that expression of proapoptotic Bax increased whereas expression of anti-apoptotic Bcl-2 genes decreased. In another study ileal samples obtained from infants undergoing surgical resection for NEC demonstrated higher levels of BNIP3 protein and authors proposed that upregulation of the cell death-related protein BNIP3 is a possible mechanism associated with enterocyte death observed in NEC. ${ }^{6}$ More recently, the sentinel immune receptor Toll-like receptor 4 (TLR4) has been identified and activation of this receptor by bacterial lipopolysaccharide has been proposed to be directly responsible for increased rates of apoptosis and impaired mucosal healing. ${ }^{11,12}$ An experimental study on mice with deficient TLR4 signaling showed that LPS-induced intestinal apoptosis was prevented and the incidence of NEC development reduced. ${ }^{11}$ Furthermore, glutamine has been shown to downregulate Tolllike receptor 2 (TLR-2) and TLR-4 expression and to protect intestine in premature neonatal rats with NEC. ${ }^{12}$ These studies provide a rationale for studying how the regulation of enterocyte apoptosis occurs within the human newborn intestine during development of NEC.
In this study, we investigated the expression of pro-apoptotic and anti-apoptotic genes, in intestines of human newborns with acute NEC. Consistent with previous reports, we detected high grade tissue injury and extensive apoptosis in enterocytes of infants with NEC when compared to controls with intestinal atresia., $2,6,7,13$ There were some degree of mild tissue injury and apoptosis in the samples from ileal atresia patients who served as our controls. It could be argued that intestinal atresia patients might not have normal tissues. We took the samples from the grossly viable looking bowels which we expected to function normally. The mild changes observed in ileal atresia patients could be reflection of the mucosal injury which might be the result of prolonged intestinal dilatation or intestinal manipulation during surgery. The increased tissue injury and apoptosis scores encountered in one of the patients could either directly related to type 4 intestinal atresia which is more severe type than the others or delayed surgery which was done postnatal day 4 in this patient.

We detected increased expression of apoptotic caspase-3, caspase-6, caspase-7, BIRC2, and Bax genes and decreased expression of anti-apoptotic

TABLE 5: The change in the expression of apoptotic and anti-apoptotic genes

\begin{tabular}{llc}
\hline Genes & Function & The change in the expression of genes \\
\hline Caspase-1 & Apoptotic, cysteine peptidase & $+0.68 \pm 0.10$ \\
Caspase-2 & Apoptotic, cysteine peptidase & $+1.15 \pm 0.07$ \\
Caspase-3 & Apoptotic, cysteine peptidase & $+6.70 \pm 1.06^{*}$ \\
Caspase-6 & Apoptotic, cysteine peptidase & $+5.33 \pm 1.60^{*}$ \\
Caspase-7 & Apoptotic, cysteine peptidase & $+10.52 \pm 2.12^{*}$ \\
Caspase-9 & Apoptotic, cysteine peptidase & $+1.21 \pm 0.02$ \\
BCL2A1 & Bcl-2 related protein A1, Anti-apoptotic & $-5.42 \pm 1.32^{*}$ \\
BIRC2 & Baculoviral IAP repeat containig 2, apoptotic & $+5.20 \pm 1.16^{*}$ \\
BAX & Bcl-2 Associated X protein, apoptotic & $+27.24 \pm 5.16^{*}$ \\
\hline
\end{tabular}

$\mathrm{n}=8$, Mean \pm SDV, ${ }^{*} \mathrm{p}<0.01$

TABLE 6: Caspase 3 and Bax protein expression in the intestinal tissue

\begin{tabular}{lccc|ccc}
\hline & \multicolumn{3}{c|}{ Control group } & \multicolumn{3}{c}{ Necrotizing enterocolitis } \\
\hline & Patologist 1 & Patologist 2 & ${ }^{*}$ Avarage & Patologist 1 & Patologist 2 & ${ }^{*}$ Avarage \\
\hline Caspase 3 expression & $34.33 \pm 4.73$ & $32.67 \pm 4.16$ & $33.5 \pm 4.44$ & $93.33 \pm 5.69$ & $86.67 \pm 7.57$ & $* * 90.00 \pm 6.63$ \\
Bax expression & $26.02 \pm 3.53$ & $29.42 \pm 3.24$ & $27.72 \pm 3.39$ & $95.33 \pm 6.96$ & $98.71 \pm 8.69$ & $* * 97.02 \pm 7.66$ \\
\hline
\end{tabular}

* \% expression **P $<0.01$ 
Bcl-2A1 gene in tissue samples of neonates with NEC. Mean protein expression percentage of Bax and caspase- 3 was significantly elevated in NEC group when compared with ileal atresia group. There were no statistically significant differences in Bad, Bcl-xL, and Bcl-w expression between NEC and ileal atresia intestines in our study. These findings of our study are in agreement with the previous experimental neonatal NEC study. ${ }^{5} \mathrm{Bcl}-2$ and Bax proteins together compose a cellular rheostat which regulates cellular transition towards or away from apoptosis., ${ }^{3,14}$ Our data showing increased caspase3,caspase- 6 and caspase-7 gene and caspase- 3 protein expression collaborate with the findings of previous study which shows supplementation with a pan-caspase inhibitor normalized the rates of apoptosis leading to decreased NEC incidence in a neonatal rat model of NEC. ${ }^{2}$

Treatment modalities which could modulate the ratio of Bax to $\mathrm{Bcl}-2$ proteins in favor of intestinal cell survival can prevent progression of apoptosis and development of NEC. Epidermal Growth factor (EGF) is one of the active growth factors which is naturally found in human milk. Clark et al. showed that in newborn rats with NEC supplementation of EGF in formula markedly decreased the Bax to $\mathrm{Bcl}-2$ mRNA and protein ratios and dramatically reduced apoptosis. ${ }^{5,15}$ Preliminary clinical trials using intravenous recombinant EGF in neonates diagnosed with NEC have been shown to increase repair of intestinal epithelium by inducing crypt cell proliferative activity. ${ }^{15}$ The beneficial effects of EGF supplementation in neonates might depend on promotion of healing of intestinal mucosal barrier, therefore prevention of development of NEC.

\section{CONCLUSION}

Our data in human newborns suggest that alteration of the balance between pro-apoptotic Bax expression and anti-apoptotic Bcl-2A1 expression can be a possible mechanism in the pathogenesis of NEC. Our study provides basis to further studies to understand the mechanisms that lead to alteration of the balance between proapoptotic and anti-apoptotic gene expression and to design future therapeutic and/or preventative strategies for NEC by modifying apoptosis.

\section{REFERENCES}

1. Dominguez KM, Moss RL. Necrotising enterocolitis. Clin Perinatol 2012;39(2):387-401.

2. Jilling T, Lu J, Jackson M, Caplan MS. Intestinal epithelial apoptosis initiates gross bowel necrosis in an experimental rat model of neonatal necrotising enterocolitis. Pediatr Res 2004;55(4):622-9.

3. Khailova L, Mount Patrick SK, Arganbright KM, Halpern $\mathrm{MD}$, et al. Bifidobacterium bifidum reduces apoptosis in the intestinal epithelium in necrotizing enterocolitis. Am J Physiol Gastrointest Liver Physiol 2010;299(5):G1118-27.

4. Maynard AA, Dvorak K, Khailova L, Dobrenen H, et al. Epidermal growth factor reduces autophagy in intestinal epithelium and in the rat model of necrotizing enterocolitis. Am J Physiol Gastrointest Liver Physiol 2010;299(3):G614-22.

5. Clark JA, Lane RH, MacLennan NK, Holubec H, et al. Epidermal growth factor reduces intestinal apoptosis in an experimental model of necrotizing enterocolitis. Am J Physiol Gastrointest Liver Physiol 2005;288(4):G755-62.

6. Zamora R, Vodovotz Y, Betten B, Wong C, et al. Intestinal and hepatic expression of BNIP3 in necrotizing enterocolitis: regulation by nitric oxide and peroxynitrite. Am J Physiol Gastrointest Liver Physiol 2005;289(5):G822-30.

7. Halpern MD, Clark JA, Saunders TA, Doelle SM, et al. Reduction of experimental necrotizing enterocolitis with anti-TNF-. Am J Physiol Gastrointest Liver Physiol 2006;290(4):G757-64.

8. Halpern MD, Weitkamp JH, Mount Patrick SK, Dobrenen HJ, et al. Apical sodium-dependent bile acid transporter upregulation is associated with necrotizing enterocolitis. Am J Physiol Gastrointest Liver Physiol 2010;299(3):G623-31.

9. Bagriacik EU, Yaman M, Haznedar R, Sucak G, Delibasi T. TSH-induced gene expression involves regulation of selfrenewal and differentiation-related genes in human bone marrow-derived mesenchymal stem cells. J Endocrinol 2012;212(2):169-78.

10. Charafe-Jauffret E, Tarpin C, Bardou VJ, Bertucci F, et al. Immunophenotypic analysis of inflammatory breast cancers: identification of an 'inflammatory signature'. J Pathol 2004;202(3):265-73.

11. Leaphart CL, Cavallo J, Gribar SC, Cetin S, et al. A critical role for TLR4 in the pathogenesis of necrotizing enterocolitis by modulating intestinal injury and repair. J Immunol 2007;179(7):4808-20.

12. Zhou W, Li W, Zheng XH, Rong X, Huang LG. Glutamine down regulates TLR-2 andTLR-4 expression and protects intestinal tract in preterm neonatal rats with necrotizing enterocolitis. J Pediatr Surg 2014;49(7):1057-63.

13. Ford $H, W a t k i n s S$, ReblockK, et al. The role of inflammatory cytokines and nitric oxide in the pathogenesis of necrotizing enterocolitis. J Pediatr Surg 1997;32(2):275-82.

14. Czabotar PE, Lessene G, Strasser A, Adams JM. Control of apoptosis by the BCL-2 protein family: implications for physiology and therapy. Nat Rev Mol Cell Biol 2014;15(1): 49-63.

15. Coursodon CF, Dvorak B. Epidermal growth factor and necrotizing enterocolitis. Curr Opin Pediatr 2012;24(2):160-4. 


\title{
Osteogenesis imperfecta: Level of independence and of social, recreational and sports participation among adolescents and youth
}

\author{
Mercedes Rodríguez Celin M.D. ${ }^{a}$ and Virginia Fano M.D. ${ }^{a}$
}

\begin{abstract}
Introduction. Osteogenesis imperfecta is a group of hereditary connective tissue disorders that cause bone fragility, with a wide clinical variability resulting in varying degrees of motor disability.

Objectives. To describe the level of independence and of social, recreational and sports participation among adolescents with osteogenesis imperfecta.

Population and methods. Descriptive, analytical and crosssectional study conducted in patients with osteogenesis imperfecta older than 15 years old attending the Skeletal Dysplasia Office of Hospital "Prof. Dr. Juan P. Garrahan" (May 2013 through December 2014). Self-administered survey. Short stature was an outcome measure that indicated severity. Results. There were 18 patients; age: 19.17 ( $\pm 3.4 \mathrm{sDE}) ; 83 \%$ had moderate-severe forms of OI; median height: $-7.9 \mathrm{sDE}$; $50 \%$ used a wheelchair.

Average education years: $12.2 ; 56 \%$ participated in sporting activities; and $78 \%$ were involved in recreational and social activities. A high level of independence was observed.

We found a correlation between short stature and use of wheelchair (r:-0.77) and between short stature and participation in sporting activities (r: 0.66 ). No correlation was observed with years of education ( $\mathrm{r}$ : -0.15), participation in social activities (r: -0.22) or recreational activities (r: 0.35).

Key words: osteogenesis imperfecta, adolescent, social participation, recreational activities.
\end{abstract}

http:/ /dx.doi.org/10.5546/aap.2016.eng.248

\section{INTRODUCTION}

Osteogenesis imperfecta (OI) is a group of hereditary connective tissue disorders that cause bone fragility. ${ }^{1}$ According to its etiology, this

a. Department of Growth and Development, Skeletal Dysplasia Office, Hospital de Pediatría

"Prof. Dr. Juan P. Garrahan", Buenos Aires, Argentina.

E-mail address: Mercedes Rodríguez Celin, M.D.: mercedesrodriguezcelin@gmail.com

Funding: None.

Conflict of interest: None.

Received: 11-03-2015

Accepted: 01-11-2016 disease is directly or indirectly related to type I collagen, ${ }^{2}$ and has a prevalence of 1 in every 12 000-15 000 newborn infants (NBIs). ${ }^{3}$

It has a wide clinical variability. The original classification made by Sillence in 1979 into type I, II, III and IV was modified by Dijk and Sillence in 2014 based on the clinical severity of OI into mild, moderate, severe and extremely severe. ${ }^{1}$ The severe forms usually show multiple fractures observed before birth and lead to skeletal deformities and complications. Other common signs include variable degrees of short stature, dental alterations and hearing loss. OI is not associated with intellectual disability. ${ }^{4}$

There is no single therapeutic scheme for OI; management should be adapted to each individual and agreed among the multidisciplinary medical team, the patient and his/her family..$^{3,5}$

A study conducted in 2011 at the Shriners Hospital for Children Canada that caters for patients with OI conducted a survey to assess the level of independence and of social, recreational and sports participation among 24 adolescent and young adult patients with OI. ${ }^{4}$

We believe that having a broader picture of these aspects regarding our group of patients with OI may help us improve treatment strategies.

\section{OBJECTIVE}

To describe the level of independence and of social, recreational and sports participation among youth with OI.

\section{POPULATION AND METHODS}

This was a descriptive, analytical, crosssectional study.

All patients with OI, older than 15 years old and attending the Skeletal Dysplasia Office of Hospital "Prof. Dr. Juan P. Garrahan" (May 2013 through December 2014) were assessed. The following clinical outcome measures were evaluated: age, sex, type of OI, zH. The latest classification published by van $\mathrm{Dijk}^{1}$ was used. All patients were invited to complete a selfadministered survey, which had been translated 
from the version prepared by the Shriners Hospital for Children Canada. ${ }^{4}$ The translation was done by one of the authors and then tested in three patients for comprehension, after which minimal grammar corrections were made. Before the survey was completed, patients gave their verbal consent to participate.

The survey included 20 questions. Questions 1-17 and 19 asked about education and work achievements, housing, transportation, relationship with the hospital and social, recreational and sports participation. Questions were close-ended, with single or multiple choice answers, depending on the question. Question 18 assessed 15 items regarding mobility, self-care and activities of daily living. These items were scored using a four-point scale (from requiring maximal assistance to being independent) and were selected from two different instruments: the Functional Independence Measure (FIM) and the Instrumental Activities Measure (IAM). ${ }^{6}$ The FIM assesses physical and cognitive impairment. The IAM was developed as a supplement to the FIM to obtain information on the level of independence. Question 20 was open-ended and asked about future plans. A copy of the questionnaire is attached in the Annex.

The measured height $\mathrm{Z}$ score $(\mathrm{zH})$ was used as an outcome measure that indicated severity (a shorter stature meant a worse severity). The independent outcome measure used for correlations was $\mathrm{zH}$. A correlation with the following selected outcome measures from the survey was sought: use of wheelchair, participation in social activities (involvement in religious groups, going to the mall or watching movies with friends, etc.), sporting activities (walking, swimming, playing basketball, etc.), recreational activities (reading, handicrafts, computer activities, etc.), and number of completed school years (completed years of mandatory education: as of 5 years old).

\section{Statistical analysis}

Data were summarized using central tendency and dispersion, as applicable. Spearman's correlation coefficient for nonparametric outcome measures was used to correlate $\mathrm{zH}$ to the different selected outcome measures.

\section{RESULTS}

\section{General characteristics of the sample}

All patients agreed to complete the questionnaire, which was self-administered by all except one patient who required help due to his motor disability.

Eighteen patients with osteogenesis imperfecta older than 15 years old were included (11 boys); their mean age was $19.17( \pm 3.4 \mathrm{sDE})$.

Of them, $83 \%$ had moderate-severe OI and $17 \%$, mild OI. Median zH was -7.9 sDE $(-14.68 /+1.5$ sDE).

\section{Questionnaire analysis}

To move around, $50 \%$ of patients used a wheelchair all the time, $17 \%$ combined a wheelchair with a walking aid, and 33\% walked on their own.

In relation to education level, work, housing and transportation, the average number of completed school years was 12.2, and $78 \%$ were in school. Among patients older than 18 years old (11 patients), 36\% were working, 69\% would like to work, and $24 \%$ believed that they required adaptations. Also, $89 \%$ lived in their family house, and $78 \%$ used public transportation, but only $29 \%$ did so in an independent manner. Only one patient drove his own car. Fifty percent got driven the family car.

Participation in social, recreational and sporting activities is described in Table 1.

In relation to the perception of their own health status, their ability to manage OI and communication with the medical team, as well as their interaction with the health system outside our hospital, $55 \%$ of patients indicated that they had an excellent health status; $39 \%$, that it was good; and only 1 patient, that it was fair. Sixtysix percent of patients received care close to their home, and 50\% referred that their doctor had qualifications to manage OI. Also, $94 \%$ of patients felt capable of managing their condition, but $61 \%$ discussed their medical needs with their doctors only sometimes and $43 \%$ were always involved in making treatment decisions.

TABLE 1. Participation in sporting, social and recreational activities among adolescents with osteogenesis imperfecta (N: 18)

\begin{tabular}{lccc}
\hline Participation & Regularly & Occasionally & Never \\
\hline Sporting & $39 \%$ & $17 \%$ & $44 \%$ \\
Social & $50 \%$ & $28 \%$ & $22 \%$ \\
Recreational & $67 \%$ & $11 \%$ & $22 \%$ \\
\hline
\end{tabular}


When asked to what extent our hospital had helped them feel healthy and independent, 95\% of assessed patients indicated that it did to a great extent. In addition, $61 \%$ of patients indicated that the hospital helped them to make their own decisions to a great extent, but only $46 \%$ referred that it helped them to a great extent to find a hospital where they could receive adult care.

The level of independence in relation to mobility, self-care and activities of daily living is described in Table 2.

Participants were invited to share their plans for the future, and all but one wrote about them. The most common plans for the future included a wish to start or complete a university degree, work and have their own family.

\section{Correlation between short stature and the different outcome measures}

A short stature measured as Z score was used as a severity outcome measure. A negative correlation was observed between $\mathrm{zH}$ and wheelchair requirement ( $r$ : 0.77). The group with the higher level of participation in sporting activities was the one less affected by short stature (r: 0.66). No correlation was observed between $\mathrm{zH}$ and years of education ( $\mathrm{r}: 0.15)$, participation in social activities ( $\mathrm{r}$ :-0.22) or recreational activities (r: 0.35).

\section{DISCUSSION}

Weaknesses of our work include that the survey was not transculturally adapted and that the sample size was not large; however, given that $\mathrm{OI}$ is a rare disease, we believe that the resulting data may be useful.

It was observed that, to varying degrees, $78 \%$ of patients participated in social and recreational activities and no correlation was found between $\mathrm{zH}$ and the frequency of such participation. Data published by Montpetit ${ }^{4}$ are similar to our results: no differences were observed in social and recreational involvement among the different types of OI. Compared to those activities, sports were practiced to a lower extent, consistent with Montpetit's reports, who observed that patients with severe forms of OI practiced fewer sporting activities. $^{4}$

The levels of independence as described by mobility, self-care and activities of daily living are high. Difficulties are consistent with those observed among patients with type III OI in the referenced publication. ${ }^{4}$

Cole $^{8}$ suggested that, although OI is associated with a normal intelligence, it may have an impact on academic performance given its major physical involvement, pain and motor disability. In our group of patients, no correlation was observed between the number of completed school years and severity, consistent with the high level of academic achievement observed in other populations with OI as reported by Montpetit ${ }^{4}$ and Widmann. ${ }^{9}$

The review conducted by Thompson ${ }^{10}$ among adults with skeletal dysplasia described varying degrees of social isolation and its influence on the

TABLE 2. Level of independence in relation to mobility, self-care and activities of daily living among patients with osteogenesis imperfecta (N: 18)

\begin{tabular}{lcccc}
\hline & Independent & $\begin{array}{c}\text { Needs minimal } \\
\text { assistance }\end{array}$ & $\begin{array}{c}\text { Needs moderate } \\
\text { assistance }\end{array}$ & $\begin{array}{c}\text { Needs maximal } \\
\text { assistance }\end{array}$ \\
\hline Feeding & 16 & 1 & 1 & 0 \\
Personal hygiene & 14 & 3 & 1 & 0 \\
Bathing/showering & 15 & 1 & 1 & 1 \\
Dressing the upper body & 18 & 0 & 0 & 0 \\
Dressing the lower body & 16 & 0 & 1 & 5 \\
Transfer to the toilet & 11 & 1 & 1 & 5 \\
Transfer to the tub/shower & 11 & 2 & 0 & 3 \\
Transfer to the wheelchair & 11 & 3 & 1 & 5 \\
Transfer to the car & 10 & 2 & 2 & 1 \\
Mobility outside the house & 14 & 1 & 1 & 1 \\
Preparing simple meals & 15 & 1 & 1 & 6 \\
Cooking and doing the dishes & 9 & 2 & 1 & 2 \\
Shopping & 14 & 1 & 1 & 5 \\
Cleaning & 9 & 3 & 2 & 5 \\
Doing the laundry & 10 & 1 & & \\
\hline
\end{tabular}


level of education attained. Attention should be paid to this aspect given that, in our study, 22\% of patients referred that they never participated in social activities.

Future studies should focus on establishing how the level of independence and participation may affect the quality of life of patients with OI. ${ }^{11,12}$

\section{Acknowledgments}

We would like to thank Mariana del Pino, M.D., for making a critical review of the article and her contributions.

\section{REFERENCES}

1. van Dijk FS, Sillence DO. Osteogenesis imperfecta: clinical diagnosis, nomenclature and severity assessment. Am J Med Genet A 2014;164A(6):1470-81.

2. Marini JC, Blissett AR. New genes in bone development: what's new in osteogenesis imperfecta. J Clin Endocrinol Metab 2013;98(8):3095-103.

3. Glorieux F. Guide to Osteogenesis Imperfecta for pediatricians and family practice physicians. Berhesda: National Institute of Health; 2007.
4. Montpetit K, Dahan-Oliel N, Ruck-Gibis J, Fassier F, et al. Activities and participation in young adults with osteogenesis imperfecta. J Ped Rehabil Med 2011;4(1):13-22.

5. Fano v, Rodriguez Celin M, del Pino M, Buceta S, et al. Osteogénesis imperfecta. Evaluación clínica, funcional y multidisciplinaria de 65 pacientes. An Pediatr (Barc) 2010;72(5):324-30.

6. Grimby G, Andrén E, Holmgren E, Wright B, etal. Structure of a combination of Functional Independence Measure and Instrumental Activity Measure Items in community-living persons: a study of individuals with cerebral palsy and spina bifida. Arch Phys Med Rehabil 1996;77(11):1109-14.

7. Ben Amor IM, Glorieux FH, Rauch F. Genotype-phenotype correlations in autosomal dominant osteogenesis imperfecta. J Osteoporos 2011;2011:540178.

8. Cole DE. Psychosocial aspects of osteogenesis imperfecta: an update. Am J Med Genet 1993;45(2):207-11.

9. Widmann RF, Laplaza FJ, Bitan FD, Brooks CE, etal. Quality of life in osteogenesis imperfecta. Int Orthop 2002;26(1):3-6.

10. Thompson S, Shakespeare T, Wright MJ. Medical and social aspects of the life course for adults with a skeletal dysplasia: a review of current knowledge. Disabil Rehabil 2008;30(1):1-12.

11. Fano v, Del Pino M, Rodríguez Celin M, Buceta S, et al. Osteogénesis imperfecta: estudio de la calidad de vida en los niños. Arch Argent Pediatr 2013;111(4):328-31.

12. Hill CL, Baird WO, Walters SJ. Quality of life in children and adolescents with Osteogenesis Imperfecta: a qualitative interview based study. Health Qual Life Outcomes 2014;12:54. 


\section{ANNEX}

First and last name:

Date of birth:

Medical record no.:

Contact number:

Date of visit:

\section{QUESTIONNAIRE}

1) Are you in school this year?

No.

Yes.

School grade:

Type of education (standard, special, home-school):

Did you repeat or miss a school year? Please describe:

2) Have you completed courses outside school?

No.

Yes. Please describe:

3.a) Are you working for a salary?

No.

1 to 10 hours per week.

11 to 25 hours per week.

26 to 40 hours per week.

Please describe what you do at work:

3.b) If you are not working, would you like to work?

Yes.

No.

Are you looking for a job?

Yes.

No.

3.c) What would help you have a job?

Transportation.

Special adaptations.

Better education or training.

Overcoming the fear to work.

My parents' approval.

4) Have you done community work (unpaid group work done for the benefit of the community)?

No.

1 to 10 hours per week.

11 to 25 hours per week.

26 to 40 hours per week.

Please describe:

5) What is your housing situation?

Living in my family home.

Living in a supervised apartment.

Living with friends.

Living with a couple.

Other. Please describe: 
6) Do you participate in sporting activities (walking, camping, swimming, playing basketball, others)? Never.

Occasionally (once or twice a month).

Regularly (once or more times a week).

Please describe:

7) Do you participate in social activities outside home (religious groups, going to the mall with friends, watching movies with friends, etc.)?

Never.

Occasionally (once or twice a month).

Regularly (once or more times a week).

Please describe:

8) Do you participate in recreational activities (reading, handicrafts, computer activities)?

Never.

Occasionally (once or twice a month).

Regularly (once or more times a week).

Please describe:

9) How do you travel around your community?

Driving your own car.

Getting driven in the family car.

Using a special transportation service.

Using public transportation.

If you use public transportation, indicate how:

On your own (you do not need assistance).

With minimal assistance (you need some help).

With moderate assistance (you need moderate help).

With maximal assistance (you need a lot of help).

10) In general, how would you describe your health status?

Excellent.

Very good.

Good.

Fair.

Poor.

11) Do you get medical care close to your home?

No. Please explain:

Yes. Please describe:

Primary care physician.

Traumatologist.

Other.

When did you last see your doctor?

12) Does your doctor have the qualifications to manage osteogenesis imperfecta?

Yes.

No.

Please describe:

13) Are you capable of taking care of yourself given your osteogenesis imperfecta?

Yes.

No. Please explain: 
14) Do you discuss your needs with your doctors?

All the time.

Sometimes.

Never.

15) Do you make your own decisions regarding your treatment plan?

All the time.

Sometimes.

Never.

16) How do you move around?

Using a wheelchair all the time.

Using a wheelchair and walking.

Walking with an aid all the time.

Walking on your own all the time.

17) What would help you increase your independence?

Transportation improvements.

Learning to drive.

Education.

A personal care assistant.

House or car modifications.

Help to get a job.

Help to manage your health condition.

Community involvement.

Support group.

More experience to make decisions.

Nothing in particular.

Other:

18) Indicate your level of independence: (Table)

\begin{tabular}{cccc} 
Independent & $\begin{array}{c}\text { Needs minimal } \\
\text { assistance }\end{array}$ & $\begin{array}{c}\text { Needs moderate } \\
\text { assistance }\end{array}$ & $\begin{array}{c}\text { Needs maximal } \\
\text { assistance }\end{array}$ \\
\hline
\end{tabular}

1. . Feeding (using cutlery and a glass).

2. Personal hygiene (combing your hair, brushing your teeth, washing your hands and face).

3. Bathing/showering (washing and drying your body).

4. Dressing your upper body (putting on a tee shirt, buttoning a jacket).

5. Dressing your lower body (putting on pants, socks, shoes, underwear).

6. Transfer to the toilet (sitting down on the toilet).

7. Transfer to the tub/shower (getting in the tub/shower).

8. Transfer to the wheelchair (sitting down on your wheelchair).

9. Transfer to the car (sitting down on the car seat).

10. Mobility outside the house (walking or using a wheelchair outside your house). 
11. Preparing a simple meal (making

a sandwich, a cup of tea or coffee).

12. Cooking (preparing food for 1 or

2 people, including doing the dishes).

13. Shopping (going to the store, picking items, taking items home).

14. Cleaning (making the beds, vacuuming, keeping the house clean).

15. Doing the laundry (sorting out clothes, using the washing machine, folding the clothes).

19) Please indicate how Hospital Garrahan has helped you with the following:

\section{To a great extent To a moderate extent To a minimum extent}

Staying healthy and being independent.

Finding a place where you can receive adult care.

Learning to make your own decisions.

20) Would you share some of your future plans with us? 